\title{
Lobbying FASB \\ On Accounting For Investments
}

Sally M. Schultz, (Email: schultzs@ newpaltz.edu), SUNY, New Paltz

Joan Hollister, (Email: Joan.Hollister@marist.edu), Marist College

\begin{abstract}
The development of SFAS No. 115, Accounting for Certain Investments in Debt and Equity Securities, serves as a case study illustrating the forces that underlie the standard setting process in the United States. This study describes the events leading to the development of the exposure draft (ED) that preceded SFAS No. 115 and analyzes the contents of the comment letters received by FASB in response to the ED; it illustrates how compromises have helped FASB maintain its role as a private sector standard setter.
\end{abstract}

\subsection{Introduction}

$T$

he standard setting process in the United States often involves compromises as the Financial Accounting Standards Board (FASB) attempts to design standards that will be supported by parties with conflicting interests. The process can be contentious. FASB is often pressured by opposing forces that may include the Securities and Exchange Commission (SEC), other government agencies, industry and professional groups, and individual companies. This paper uses the development of Statement of Financial Accounting Standards (SFAS) No. 115, Accounting for Certain Investments in Debt and Equity Securities, to illustrate the political nature of the standard setting process, which tends to (1) make generally accepted accounting principles (GAAP) logically inconsistent, (2) ensure that someone is unhappy with the standards, (3) make changes in GAAP inevitable, and (4) make it difficult to change standards quickly (Miller, et al., 1998).

Prior to examining the SFAS No. 115 project, we discuss the role of lobbying in the standard setting process and review the evolution of accounting standards for investments in the U.S. (other than those related to the equity method and consolidation issues). The comment letters to the exposure draft (FASB 1992) that preceded SFAS No. 115 are then analyzed, as are the changes between the proposed and final statements.

\subsection{Lobbying and the Standards Setting Process}

The power to set accounting standards in the U.S. was granted to the Securities and Exchange Commission (SEC) under the Securities Exchange Act of 1934. However, the SEC has largely relied on the private sector to develop accounting principles. At the same time, it has often worked to change accounting standards by serving as "the sand in the oyster" to foster the process of innovation in accounting (Burton 1982).

In its role as private sector standards setter, FASB is committed to weighing the views of its constituents in order to develop standards with a broad base of support. Because constituents have disparate and conflicting interests, politics is an inherent part of the standard setting process. FASB's decisions are constrained both by the need to maintain continuing support from its constituents and by the need to find a consensus solution that can garner the support of the Board.

Readers with comments or questions are encouraged to contact the authors via email. 
Lobbying can be conducted through formal or informal channels. Since informal lobbying can be hard to assess, much of the lobbying research focuses on formal submissions made by respondents to exposure drafts. Lobbying studies have been conducted using submissions to various standard setting groups, including a number that have examined constituent lobbying of FASB on proposed accounting standards, including foreign currency (Kelly 1982, 1985; Kirsch et al. 1990), pension and other postretirement benefits accounting (Francis 1987, Ndubizu et al. 1993, Kreuze et al. 1993), interest costs (Dhaliwal 1982), employee stock-based compensation (Dechow et al. 1996), oil and gas accounting (Deakin 1989), and bank and savings and loan accounting (Meier et al. 1993). Some researchers have sought to develop statistical models to explain differences between lobbying and non-lobbying firms (e.g., Francis 1987), or between firms lobbying in favor of versus against a particular proposal (e.g., Kirsch et al. 1990). Other studies sought to be primarily descriptive in nature, focusing on a comparison of the types of respondents (e.g. Kenny and Larson 1995, Tandy and Wilburn 1992, Tutticci et al. 1994) or on an analysis of the source and content of comment letters and their impact on the final standard (e.g., Kenny and Larson 1993, Kaplan and Pany 1992, Buckmaster and Hall 1990, Kreuze et al. 1993).

This study provides descriptive evidence about lobbying behavior based upon a content analysis of comment letters received in response to the 1992 exposure draft (ED) that preceding SFAS No. 115. It addresses the following research questions:

a) What constituent groups lobbied FASB and how did the responses differ based upon industry affiliation?

b) What positions did the respondents take on the ten policy issues raised by FASB? Were there any significant differences between constituent groups on these issues?

c) What economic consequences and other supporting arguments were most frequently cited to buttress respondents' views?

d) What changes were made between the ED and SFAS No. 115, and to what extent were these changes consistent with the respondents' positions on the issues?

\subsection{Accounting for Investments}

In 1947, Accounting Research Bulletin (ARB) No. 30 noted that: "practice varies with respect to the carrying basis for current assets such as marketable securities and inventories" (subsequently restated in ARB No. 43, Chapter 3A, paragraph 9). The recommendation was that securities should be marked down to market value when it was substantially less than cost and the decline was considered to be other than temporary. At the beginning of the FASB era, enterprises were carrying marketable securities at cost, market value, or lower-of-cost-or-market. Market values declines during 1973 and 1974 meant that some enterprises were carrying securities at cost in excess of current market value. Other enterprises wrote down their securities to reflect the market decline. When prices partially recovered in 1975, these securities were being carried at amounts below both original cost and current market value. These conditions, and concern over the lack of definitive guidance in the authoritative literature, led to requests for FASB to consider these problems.

SFAS No. 12 (FASB 1975) advocated the lower-of-cost-or-market rule for valuing investments in marketable equity securities. The lower-of-cost-or-market calculation would be applied separately to a current and a non-current investment portfolio. Adjustments required to restate the current portfolio to lower-of-cost-or-market value would be reported in income, but those related to the non-current portfolio would be reported in a separate equity account.

SFAS No. 12 did not address the measurement of investments in debt securities, which subsequently were typically accounted for at amortized cost. Deregulation of interest rates and the advent of new products to manage interest rate risk created new incentives to dispose of debt instruments before maturity. Given this increased speculative activity, regulators of depository institutions began to question use of amortized cost to value securities that were being traded. They were also concerned about "gains trading" by managers who sold appreciated securities to recognize gains and held depreciated securities to avoid recognizing losses. The SEC shared these concerns, and in 1989 they urged the AICPA'S Accounting Standards Executive Committee (AcSEC) to tighten rules for the classification of securities. 
AcSEC subsequently issued a proposed Statement of Position (SOP) that restricted amortized cost accounting to those securities that the enterprise had both the intent to hold for the foreseeable future and the ability to hold until maturity (AICPA 1990a). Other investments in debt securities would be valued at lower-of-cost-or-market with a corresponding charge to income. In response, AcSEC received about 400 comment letters critical of any attempt to move away from the use of amortized cost for debt securities, including a number from bankers concerned that the lower-of-cost-or-market method would cause earnings to fluctuate too much.

The SEC was also critical of AcSEC's proposal, but on the grounds that it had not sufficiently embraced market value accounting. Valuing the mortgage portfolios of savings and loans at cost was believed to have been a major factor in disguising the insolvency of the thrift industry. The savings and loan crisis had been costly and the SEC was now advocating rapid movement to market-based valuations. In the SEC's view, volatility was something that accounting statements should attempt to portray rather than conceal (Salwen and Block 1990; Johnson and Swieringa 1996, 158). However, the Federal Reserve Board sided with the banks, arguing that earnings volatility could reduce the amount of marketable securities that banks were willing to hold and so reduce bank liquidity (Duke and Salwen 1990; Johnson and Swieringa 1996, 159-160).

In light of these criticisms, AcSEC decided to postpone issuing measurement guidance and it encouraged FASB to undertake a project on accounting for investments. As an interim measure, AcSEC issued SOP 90-11, which required disclosure of the market value of debt securities held by financial institutions (AICPA 1990b). FASB had already begun considering the issue of disclosures of financial instruments, and ultimately issued SFAS No. 105 in 1990 and SFAS No. 107 in 1991. As FASB had advanced its proposals to disclose fair values, bankers were particularly vocal in their opposition, arguing that it would be difficult to pin a precise market value on local bonds and loans (Berton 1990).

Because value changes were reported only in the financial statement notes, SFAS No. 107 had not gone as far as the SEC wanted, and it began to step up the pressure on FASB to force banks and thrifts to report current values on the balance sheet (Salwen 1992). Although FASB had been on the verge of issuing a proposed rule requiring firms to report investment securities at current market value with unrealized gains and losses reported in income, a last minute vote change upset the majority needed to issue the proposal (Berton 1992a). Concerns about this proposal had also been expressed by the Treasury Secretary and the Federal Deposit Insurance Corporation (FDIC) chair. Citing the bankers' concerns, they argued that volatility of earnings and capital could force banks to reduce their holdings of mortgage-backed and municipal securities, disrupting those markets. They noted that many bank assets and liabilities could not easily be marked to market, but believed that if FASB were to require assets to be marked to market, it should also consider marking liabilities to market. (Wall Street Journal 1992a, 1992b).

In response to these pressures, FASB decided to reconsider revaluing liabilities as well as assets, which delayed progress on the project (Berton 1992b, 1992c). However, the issues of which liabilities to measure at current value and how to determine these values proved to be thorny and FASB ultimately reached an impasse on these liability questions. It then backed an approach intended as a compromise with the banks, which ultimately formed the basis for the $1992 \mathrm{ED}$. This approach provided that debt investments could be carried at amortized cost as long as the firm had the positive intent and ability to hold the securities until maturity. Investments that were not classified as held-to-maturity would be classified as either trading or available-for-sale investments and reported at fair value on the balance sheet. Unrealized gains and losses on trading securities would be reported in net income, but those on available-for-sale securities would be reported in shareholders' equity, a compromise that limited the proposal's impact on the income statement. (Later, the issuance of SFAS No. 130 (FASB 1997, par. 17) required that gains and losses on available-for-sale investments be reported as a component of other comprehensive income.)

As one senior FASB official conceded, the new approach probably wouldn't make anyone happy (Berton 1992d). The bankers' were concerned that it would severely limit their ability to use the amortized cost method, causing volatility in shareholders' equity. The SEC lauded the requirement to carry more securities at market value, but was concerned because the proposal still allowed for discretionary income recognition via gains trading. The 
availability of three different classifications for the same securities based upon management's intent was also criticized as "psychoanalytic accounting" (Berton 1992d; Blumenthal 1992). From the academic community came the criticism that the bankers seemed to be successfully defending their right to obscure the effects of economic forces on their institutions, with FASB apparently feeling that "it can't do what it oughta do" (Staubus 1992, 16).

\subsection{Methodology And Results of the Content Analysis}

Accounting for investments was a politically charged topic even before it appeared on FASB's agenda and lobbying continued as FASB tackled the issue. Constituents' responses to FASB's 1992 ED are discussed in this section of the paper. FASB received 489 comment letters, of which there were 483 usable responses that formed the basis for our content analysis. The overall number of comment letters received in response to an exposure draft can be interpreted as a measure of the level of interest in the issue. The number received in response to the investments ED exceeds those received in response to the EDs preceding such substantive statements as SFAS No. 87, Employers' Accounting for Pensions; SFAS No. 95, Statement of Cash Flows; and SFAS No. 96, Accounting for Income Taxes, which ranged from 406 to 459 letters, and were among the highest response rates of the statements studied by Tandy and Wilson (1992).

For this study, constituents were grouped into the following industry groups: banking (banks and banking associations), insurance (insurance companies and industry associations), accounting (CPA firms and accounting organizations), business (other industrial firms), and sundry (academics, individuals, governmental units and associations not categorized with an industry group). Table 1 reports the respondents' stated positions on FASB's proposal, categorized by industry affiliation. Given their long-standing interest in this issue, it is not surprising that over 60 percent of the letters received were from the banking industry, while the other groups each provided less than 15 percent of the respondents. Although applicable to all firms, the ED's greatest impact would be on financial institutions because of their proportionally greater investments in securities.

\begin{tabular}{|lrrr|r|}
\hline \multicolumn{5}{c|}{ Table 1 } \\
\multicolumn{4}{|c}{ Respondents' Stated Positions on FASB's Proposal } \\
\cline { 2 - 5 } \multicolumn{4}{c}{ Position on proposal } \\
\hline Industry & Opposed & In favor & None & \\
\hline Banking & 264 & 8 & 25 & 297 \\
Insurance & 60 & 0 & 1 & 61 \\
Business & 33 & 12 & 5 & 50 \\
Accounting & 27 & 8 & 8 & 43 \\
Sundry & 16 & 9 & 7 & 32 \\
Total & 400 & 37 & 46 & 483 \\
Note: The Pearson Chi-Square statistic based upon cross- \\
classifying the opposed respondents versus the remaining \\
respondents was significant at the .01 level. \\
\hline
\end{tabular}

Overall, 83 percent of the respondents were writing to oppose FASB's ED. This opposition is apparent in all constituent groups. These results are consistent with those reported by Mezias and Chung $(1989,13)$, who found that comment letters generally tended to oppose alternatives advanced by the Board. In the present study, significant differences appear between constituent groups, with the banking and insurance industries having proportionally more respondents opposing the proposed statement.

Table 2 provides evidence about the relationship between the respondents' positions on the ED and their positions on the use of fair value accounting (for those who stated positions on both issues). Respondents who favored neither FASB's proposal nor the use of fair value accounting (the no-no group) were the most prevalent in each industry category. However, while 95 percent of the banking and insurance respondents were in the "no-no" group, only 70 percent of those in the business category took this position, and even fewer did in the accounting and sundry categories. Respondents who favored mark to market accounting but did not support FASB's ED approach were most prevalent in the accounting and sundry categories, apparently believing that FASB had not gone far enough in applying fair value accounting. 


\begin{tabular}{|c|c|c|c|}
\hline \multicolumn{4}{|c|}{$\begin{array}{c}\text { Table } 2 \\
\text { Respondents' Positions on FASB's Proposal and on } \\
\text { Fair Value Accounting }\end{array}$} \\
\hline \multirow[b]{2}{*}{ Industry } & \multirow{2}{*}{$\begin{array}{l}\text { In favor of } \\
\text { FASB } \\
\text { proposal? }\end{array}$} & \multicolumn{2}{|c|}{$\begin{array}{c}\text { In favor of fair } \\
\text { value accounting? }\end{array}$} \\
\hline & & Yes & No \\
\hline \multirow{2}{*}{$\begin{array}{l}\text { Banking } \\
(\mathrm{n}=250)\end{array}$} & Yes & $2 \%$ & $1 \%$ \\
\hline & No & $2 \%$ & $95 \%$ \\
\hline \multirow{2}{*}{$\begin{array}{l}\text { Insurance } \\
(\mathrm{n}=57)\end{array}$} & Yes & $0 \%$ & $0 \%$ \\
\hline & No & $4 \%$ & $96 \%$ \\
\hline \multirow{2}{*}{$\begin{array}{l}\text { Business } \\
(\mathrm{n}=37)\end{array}$} & Yes & $30 \%$ & $0 \%$ \\
\hline & No & $0 \%$ & $70 \%$ \\
\hline \multirow{2}{*}{$\begin{array}{l}\text { Accounting } \\
(n=32)\end{array}$} & Yes & $22 \%$ & $0 \%$ \\
\hline & No & $31 \%$ & $47 \%$ \\
\hline \multirow{2}{*}{$\begin{array}{l}\text { Sundry } \\
(\mathrm{n}=20)\end{array}$} & Yes & $30 \%$ & $5 \%$ \\
\hline & No & $25 \%$ & $40 \%$ \\
\hline \multicolumn{4}{|c|}{$\begin{array}{l}\text { Note: Cell contents are percentages of respondents } \\
\text { within each industry category. Only respondents } \\
\text { whose positions could be ascertained on issues were } \\
\text { included in the analysis. }\end{array}$} \\
\hline
\end{tabular}

\subsection{Responses to Issues Raised by FASB}

The analysis also identified respondents' stated support or opposition to the specific issues raised in the "Notice for Recipients of the Exposure Draft" section that prefaced the ED. These ten issues are summarized in Table 3 and the responses to them are depicted in Figure 1. The most frequently cited issue concerned whether liabilities should be included in the scope of the final statement. Only 39 percent of the respondents addressed this issue, of which nearly 80 percent advocated including liabilities in the scope. Indeed, only three issues were addressed by more than 25 percent of the respondents, with most of the remaining issues addressed by between 15 and 20 percent of the respondents.

The next two most popular issues related to intent. Whether intent should be a basis of accounting was addressed by 27 percent of the respondents, with 76 percent of those responding to the issue favoring reliance on intent. Similarly, 31 percent of the constituents addressed the need for additional provisions to operationalize intent, of which 87 percent supported the need for additional provisions.

Table 4 illustrates that the response rates to these issues differed based upon industry affiliation. Bankers did not have high response rates to any of the issues raised by FASB, with only two issues - whether additional provisions were needed to operationalize intent and whether liability accounting should be addressed-addressed by more than 20 percent of the bankers, who were apparently more interested in stating their general opposition to the ED (likely as part of an organized lobbying effort by the industry). With one exception, insurance respondents also had low response rates to particular issues. In contrast, the other constituent groups were considerably more likely to address the specific issues raised by FASB.

Similarly, Tutticci et al. $(1994,101)$ found that accounting firms addressed the greatest number of issues in a study of submissions to Australia's Accounting Standards Review Board, and speculated that "as representatives of the accounting profession, individual accounting firms may be socially and politically motivated to attempt to retain influence of the standard-setting process through the supply of detailed and erudite submissions." Along the same lines, Kaplan and Pany (1992) reported that the largest CPA firms provided the most detailed input into the decision process of the U.S. Auditing Standards Board. Other studies have also reported differences in lobbying behavior between constituent groups (Tandy and Wilburn 1992; Kreuze, et al. 1993), consistent with the supposition that constituents have disparate and conflicting interests.

\subsection{Economic Consequences Arguments}

In the lobbying literature, economic consequences arguments have been identified in content analysis case studies by MacArthur (1996) and Tutticci et al. (1994). In the present study, we identified eleven arguments in an initial screening of the comment letters commonly used by respondents to support their positions. Table 5 lists these

\section{Table 3}

Issues Raised by FASB for Constituents to Address

1. Should intent be used as a basis for accounting? Are assertions of management's intent an appropriate basis on which to 
distinguish between securities to be held-to-maturity and those available-for-sale?

2. Are any additional provisions needed to make the use of intent operational? For example, should the sale of a held-tomaturity security negate the asserted intent to hold the other securities in that category to maturity?

3. Should liability accounting be addressed in the statement? The ED addressed accounting for investments in debt and equity securities, but did not address accounting for liabilities.

4. Should additional provisions to eliminate gains trading be included in the statement? The ED excluded unrealized holding gains and losses on available-for-sale securities from earnings, so that the opportunity for gains trading in the income statement still exists.

5. Should transfers between portfolio categories be at fair value? The ED accounted for transfers between categories at fair value with any unrealized holding gain or loss reported in earnings. Should transfers instead be accounted for at amortized cost or should unrealized holding gains or losses be deferred?

6. Should the effective date of the statement be the beginning of 1994 for entities with calendar-year fiscal years?

7. Should the statement permit disclosure of the pro forma effects of retroactive application? The ED would have prohibited disclosure of pro forma effects, because they could only be based on making retrospective assumptions about management's intent.

8. Is the distinction between measuring impairment of debt securities under the investments ED and measuring impairment of loans that are not securities under the loan impairment ED appropriate? The investments ED required that impairment be measured based on fair value. Accordingly, the Board planned to eliminate investments in debt securities from the scope of the ED, Accounting by Creditors for Impairment of a Loan, which required that impairment be measured by discounting expected cash flows at the security's effective interest rate.

9. Should the proposed statement provide detailed guidance on other-than-temporary impairment? The ED did not provide comprehensive guidance on other-than-temporary impairment, which involved issues beyond the scope of the project.

10. Are the disclosures required by the ED sufficient?

issues, which represent economic consequences arguments with the exception of three issues (c, g, and h) that relate primarily to theoretical or implementation issues. Table 6 reports the number of respondents that cited each of these issues in their submissions to the Board, classified by industry. The most frequently cited arguments were that (a) volatility would be misleading, (b) the proposal would have a negative impact on earnings and capital, (c) the approach was piecemeal, and (d) the market for long-term capital would be impaired. Over 48 percent of the insurance respondents cited these four arguments. The bankers cited a broader range of issues than the insurance respondents, but in lower proportions. The remaining constituent groups did not use these arguments as widely.

\subsection{Differences Between the Exposure Draft and SFAS No. 115}

Table 7 compares FASB's positions in SFAS No. 115 on the ten issues on which feedback was sought (see Table 3) with its positions in the ED, and juxtaposes those to constituents' responses to those issues. The Board did not include liabilities in the scope of the final statement - the most frequently cited of the issues - although more than three-quarters of those addressing that issue favored including them. Although the Board believed it would have been preferable to include liabilities in the scope of the statement, they were "unable to identify, and respondents did not propose, any approach for valuing liabilities that the Board considered workable and not unacceptably complex or permissive" (FASB, 1993, par. 51).

Two of the three issues addressed by more than $25 \%$ of the respondents related to whether intent should be a basis for accounting and whether additional provisions were needed to operationalize intent. More than three-quarters of those responding to these issues favored both the use of intent and the need for additional provisions to operationalize it. Intent continues to be a basis for accounting in the final statement and additional guidance has been provided to help operationalize it. SFAS No. 115 included a more detailed description of the conditions under 


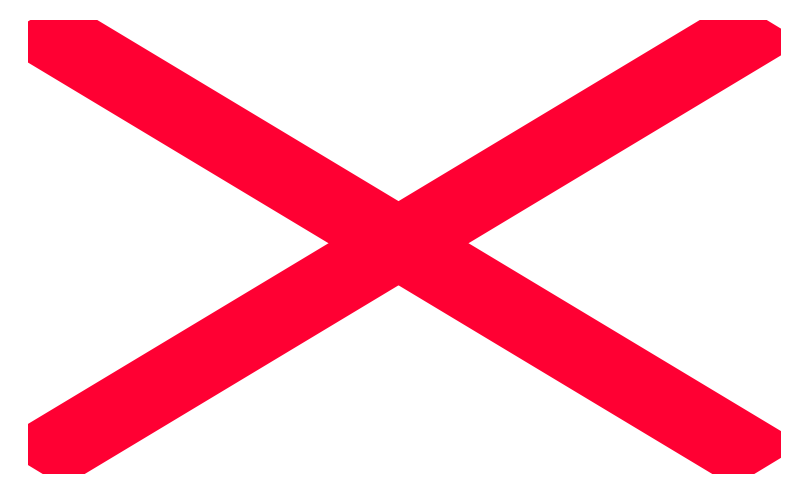

which a debt security could be classified as held-to-maturity, as well as an expanded listing of the changed circumstances justifying a security's reclassification from the held-to-maturity category without raising the question of whether others could be held to maturity in the future.

No additional provisions to eliminate the opportunity for gains trading were included in the final statement, consistent with the input provided by respondents. The final statement provided more detailed guidance on the disposition of unrealized gains or losses for transfers between categories, but maintained the requirement that transfers be accounted for at fair value. To address the gains trading concern, the Board decided that unrealized holding gains and losses would be recognized in earnings only if the security was transferred into the trading category; in other cases, any previously unrecognized gains or losses would be reported in a separate component of equity.

Consistent with the ED, SFAS No. 115 required application at the beginning of an enterprise's fiscal year and was effective for fiscal years beginning after December 15, 1993. Retroactive application and disclosure of the pro forma effects of such application were prohibited. SFAS No. 115 maintained the same distinction between impaired securities and loans and the same disclosure requirements as the ED. The ED had specified that available for sale and held-to-maturity securities should be written down to fair value when the decline in value was considered other than temporary. Respondents supported the need for more detailed guidance on other than temporary impairment, and SFAS No. 115 included one example of a situation considered to lead to other than temporary impairment.

FASB's final positions on the specific issues raised in the ED were consistent with the preferences stated by the respondents except on the issues of addressing liability accounting and making portfolio transfers at fair value. The main changes between the ED and SFAS No. 115 were to include additional guidance for operationalizing intent and for determining when impairment was other than temporary. FASB's overall approach to accounting for 


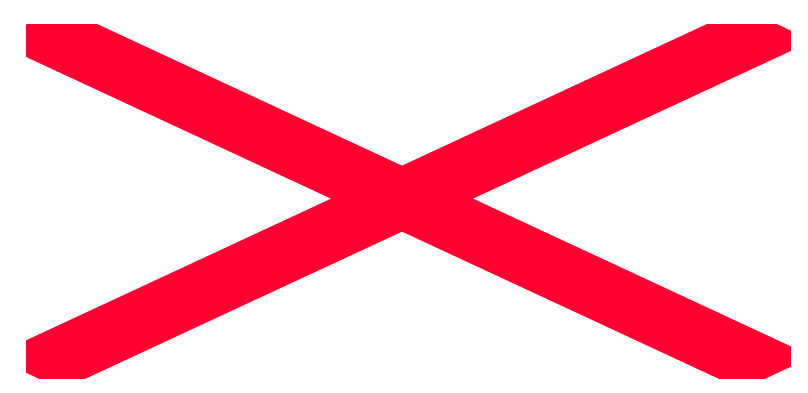

investments remained unchanged despite the respondents' overwhelming opposition to it. Thus, it seems that opponents of mark to market accounting had their major impact during the deliberations prior to the issuance of the ED.

\subsection{Conclusions}

SFAS No. 115 can be used to illustrate the four implications that Miller, et al. $(1998,29-30)$ identified as resulting from the political nature of the standard setting process. The first implication is that politics tends to make generally accepted accounting principles logically inconsistent, since they are shaped by consensus. Although SFAS No. 115 reduced the diversity in accounting practices between industries, it also introduced new comparability issues because identical debt securities might be classified three different ways depending upon management's intent. The FASB members who dissented from SFAS No. 115 argued that intent was a subjective notion not likely to be applied consistently.

The second implication is that, given constituents' different interests and the need to compromise, it is virtually certain that someone will be unhappy with the outcome. In the case of SFAS No. 115, the dissenting Board members and the SEC were unhappy because fair value accounting was not applied to all investments and unrealized gains and losses were not all reported in income. As a result, managers would have the continued opportunity to engage in gains trading. Others opposed the application of fair value accounting to assets without also applying it to liabilities. The banking and insurance industries continued to be concerned that reporting securities at fair value would lead to volatility in earnings and equity.

The third implication is that changes in GAAP are inevitable, given the dynamics of politics and the shifts in priorities. In the investments case, the SEC had begun pressuring the profession to move towards mark to market accounting and it would have been difficult for the profession to resist change in this direction. On the other hand, 


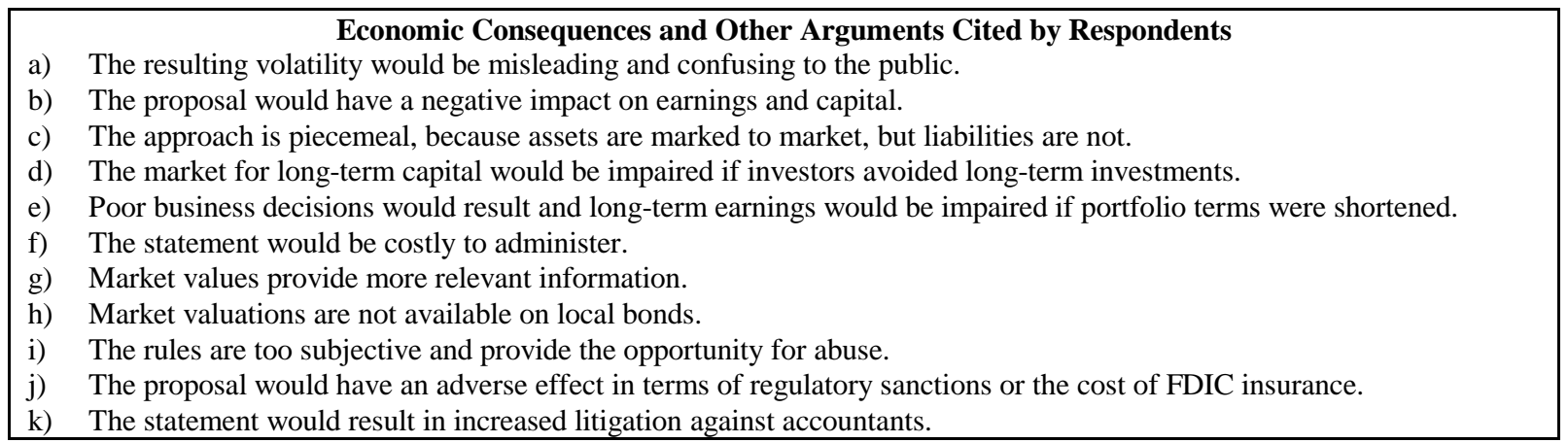

the fourth implication is that GAAP cannot be changed quickly. Agents for change must rally their forces to get a project on the agenda and keep it moving forward despite opposition from those who prefer the status quo. Change in accounting is typically evolutionary rather than revolutionary, as can been seen in the investments case. In issuing SFAS No. 115, FASB (1993, par. 87) acknowledged that it was an interim solution needed to address the existing diversity in accounting guidance. In the future, FASB may be able to achieve broader application of fair market valuation.

Those who see the public interest as best served by the SEC's recommendation for fair value accounting may conclude that FASB acted irresponsibly in incorporating compromises into SFAS No. 115. Others view compromise as necessary to garner support for the final statement and for the standard setting process. The SEC was able to act as the sand in the oyster fostering change to promote the public interest. Although neither the SEC nor the bankers achieved their goals in the case of SFAS No. 115, both had a major impact on the standard setting process.

\subsection{Suggestions for Future Research}

Lobbying research is largely based upon formal submissions to standard setting groups. As this study shows, standards are often shaped by less formal means of communication. More research into the informal aspects of the lobbying process would help document how standards are impacted by such communications and also help determine if the process might be modified to allow for more meaningful and timely input by those lobbying in the public interest. Given the recent accounting scandals at firms such as Enron and WorldCom, the time is ripe for studies that examine how corporations may have influenced accounting standards in order to portray financial data that is technically in accordance with GAAP, but which does not fairly represent a company's results. Another interesting research question is whether specific groups (including the SEC and Congress) will become more involved in lobbying FASB, either formally or informally, "post Enron." 

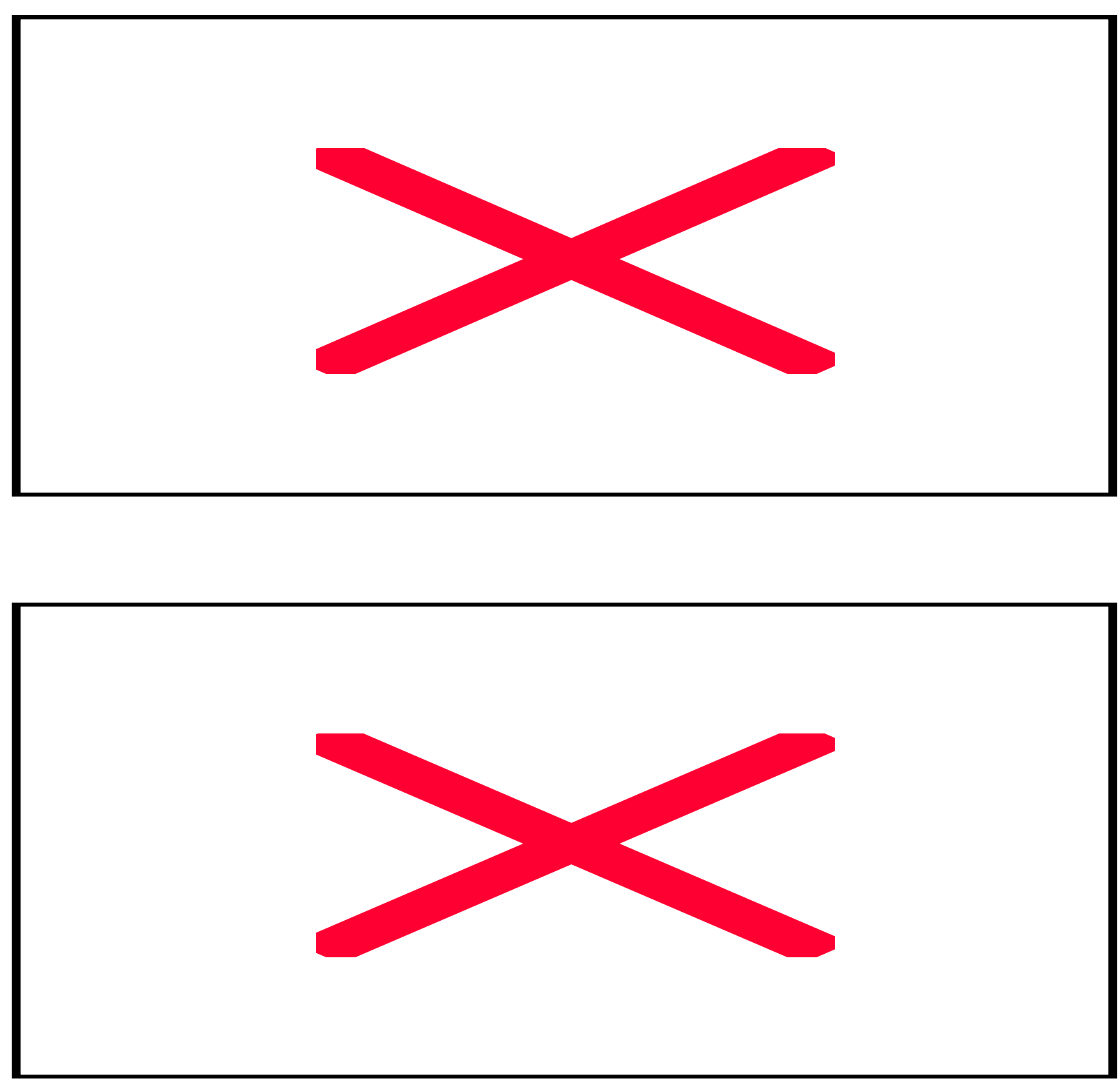


\section{References}

1. American Institute of Accountants, Committee on Accounting Procedure, Current Assets and Current Liabilities: Working Capital, Accounting Research Bulletin No.30, AI\{CP\}A, New York, 1947.

2. Restatement and Revision of Accounting Research Bulletins, Accounting Research Bulletin No. 43, AI\{CP $\}$ A, New York, 1953.

3. American Institute of Certified Public Accountants, Reporting by Financial Institutions of Debt Securities Held as Assets, Proposed Statement of Position, AICPA, New York, 1990a.

4. ㄴ. Disclosure of Certain Information by Financial Institutions About Debt Securities Held as Assets, Statement of Position 90-11, AICPA, New York, 1990b.

5. Berton, L., "Disclosure of Current Securities Values Held by Firms is Gaining Momentum," Wall Street Journal, p. A3, December 21, 1990.

6. - "FASB Balks on Current-Market Rules for Banks as Member Switches His Vote," Wall Street Journal, p. A3, January 16, 1992(a).

7. _ _ _FASB Votes to Ease Impact of Proposal," Wall Street Journal, p. A3, March 18, 1992(b).

8. $\quad$ 1992c. "FASB Delays Project to Alter Rule for Banks," Wall Street Journal, p. A3, June 11, $1992\{c\}$.

9. _ _Accounting Body Backs Modified Rules on the Valuation of Securities by Banks," Wall Street Journal, p. A2, July 16, 1992(d).

10. Blumenthal, R.G., "FASB Moves Closer to Forcing Banks to Value Securities Near Market Prices," Wall Street Journal, p. A2, September 11, 1992.

11. Buckmaster, D. and D. Hall, "Lobbying With the FASB: The Case of Accounting for Pension Terminations and Curtailments," The Journal of Applied Business Research, Vol. 6, No. 2, pp. 23-31, 1990.

12. Burton, J.C., "The SEC and Financial Reporting: The Sand in the Oyster," Journal of Accountancy, Vol. 153, No. 6, pp. 34-48, June 1982.

13. Deakin, E.B., "Rational Economic Behavior and Lobbying on Accounting Issues: Evidence from the Oil and Gas Industry," The Accounting Review, Vol. 64, No. 1, pp. 137-151, 1989.

14. Dechow, P.M., A. P. Hutton, and R.G. Sloan, "Economic Consequences of Accounting for Stock Based Compensation," Journal of Accounting Research, Vol. 34 Supplement, pp. 1-20, 1996.

15. Dhaliwal, D.S., "Some Economic Determinants of Management Lobbying for Alternative Methods of Accounting: Evidence From the Accounting for Interest Costs Issue," Journal of Business, Finance \& Accounting, Vol. 9, No. 2, pp. 255-265, 1982.

16. Duke, Jr. P. and Salwen, K.G., "SEC Proposal Draws Criticism From Greenspan-Fed Chief Says Overhauling Financial Accounting Would Cause Volatility," The Wall Street Journal, pp. A3, November 8, 1990.

17. Financial Accounting Standards Board, Accounting for Certain Marketable Securities, Statement No. 12, FASB, Stamford, CT, 1975.

18. Disclosure of Information about Financial Instruments with Off-Balance-Sheet Risk and Financial Instruments with Concentrations of Credit Risk, Statement No. 105, FASB, Norwalk, CT, 1990.

19. Disclosures about Fair Value of Financial Instruments, Statement No. 107, Norwalk, CT: FASB, 1991.

20. _ Accounting for Certain Investments in Debt And Equity Securities, Exposure Draft, FASB, Norwalk, CT, 1992.

21. Accounting for Certain Investments in Debt and Equity Securities, Statement No. 115, FASB, Norwalk, CT, 1993.

22. _ _ Reporting Comprehensive Income, Statement No. 130, FASB, Norwalk, CT, 1997.

23. Francis, J.R., "Lobbying Against Proposed Accounting Standards: The Case of Employers' Pension Accounting," Journal of Accounting and Public Policy, Vol. 6, pp.35-57, 1987.

24. Johnson, L.T. and R.J. Swieringa, "Anatomy of an Agenda Decision: Statement No. 115," Accounting Horizons, Vol. 10, No. 2, pp. 149-179, 1996.

25. Kaplan, S. and K. Pany, "A Study of Public Comment Letters on the Auditor's Consideration of the Going Concern Issue SAS 59," Research in Accounting Regulation, Vol. 6, pp. 3-23, 1992. 
26. Kelly, L., "Corporate Lobbying and Changes in Financing or Operating Activities in Reaction to FAS No. 8," Journal of Accounting and Public Policy, Vol. 1, pp. 153-173, 1982.

27. Kenny, S.Y. and R.K. Larson, "Lobbying Behavior and the Development of International Accounting Standards," European Accounting Review, Vol. 3, pp. 531-554, 1993.

28. $\longrightarrow$ "The Development of International Accounting Standards: An Analysis of Constituent Participation in Standard-Setting," The International Journal of Accounting, Vol. 30, pp. 283-301, 1995.

29. Kirsch, R.J., T.G. Evans, and T.S. Doupnik, "FASB Statement 52, An Accounting Policy Intervention: U.S.Based Multinational Corporate Preenactment Lobbying Behavior," Advances in International Accounting, Vol. 3, pp. 155-171, 1990.

30. Kreuze, J.G., S.A. Langsam and G.E. Newell, "Accounting for Nonpension Postretirement Benefits: Analysis of Lobbying Activities," Mid American Journal of Business, Vol. 8, No. 1, pp. 25-32, 1993.

31. Larson, R.K., "Corporate Lobbying of the International Accounting Standards Committee," Journal of International Financial Management \& Accounting,. Vol. 8, No. 3, pp. 175-203, 1997.

32. MacArthur, J.B., "Investigation Into the Influence of Cultural Factors in the International Lobbying of the International Accounting Standards Committee: The Case of E32, Comparability of Financial Statements," The International Journal of Accounting, Vol. 31, No. 2, pp. 213-237, 1996.

33. Meier, H.H., P. Alam, and M.A. Pearson, "Auditor Lobbying for Accounting Standards: The Case of Banks and Savings and Loan Associations," Accounting and Business Research, Vol. 23, No. 92, pp. 477-487, 1993.

34. Mezias, S.J. and S. Chung. Due Process and Participation at the FASB: A Study of the Comment Period. Financial Executives Research Foundation, Morristown, NJ, 1989.

35. Miller, P.B.W., R.J. Redding and P.R. Bahnson, The FASB: The People, the Process, and the Politics (Fourth Edition), Irwin McGraw Hill, Boston, MA, 1998.

36. Ndubizu, G.A., Y.C. Choi and R. Jain, "Corporate Lobbying Strategy and Pension Accounting Deliberations: An Empirical Analysis," Accounting, Auditing and Finance, Vol. 8, No. 3, pp. 277-287, 1993.

37. Salwen, K.G., "SEC is Seeking Updated Rules for Accounting," The Wall Street Journal, p. A3, January 8, 1992.

38. Salwen, K.G. and S. Block, "SEC Alarmed by Accounting Standards Industry Adopted For Financial Concerns," The Wall Street Journal, p. A5, September 17, 1990.

39. Staubus, G.J., "Cherry Pickers' Friend: FASB Proposal Caters to Banks, Insurers," Barron's, pp. 16-17, December 7, 1992.

40. Tandy, P.R. and N.L. Wilburn, "Constituent Participation in Standard-Setting: The FASB's First 100 Statements," Accounting Horizons, Vol. 6, No.2, pp. 47-58, 1992.

41. Tutticci, I., K. Dunstan, and S. Holmes, "Respondent Lobbying in the Australian Accounting StandardSetting Process: ED 49-A Case Study," Accounting, Auditing and Accountability Journal, Vol. 7, No. 2, pp. 86-104, 1994.

42. Wall Street Journal, "FASB is Pressured to Drop or Delay Mark-to-Market Plan," The Wall Street Journal, p. A5, March 16, 1992(a).

43. $\quad$ "Brady Asks FASB to Drop Its Proposal on Valuing Securities," The Wall Street Journal, March 25, 1992(b). 


$$
\begin{array}{|l|}
\hline x \\
\hline x
\end{array}
$$




\begin{abstract}
Table 3
Issues Raised by FASB for Constituents to Address

11. Should intent be used as a basis for accounting? Are assertions of management's intent an appropriate basis on which to distinguish between securities to be held-to-maturity and those available-for-sale?

12. Are any additional provisions needed to make the use of intent operational? For example, should the sale of a held-to-maturity security negate the asserted intent to hold the other securities in that category to maturity?

13. Should liability accounting be addressed in the statement? The ED addressed accounting for investments in debt and equity securities, but did not address accounting for liabilities.

14. Should additional provisions to eliminate gains trading be included in the statement? The ED excluded unrealized holding gains and losses on available-for-sale securities from earnings, so that the opportunity for gains trading in the income statement still exists.

15. Should transfers between portfolio categories be at fair value? The ED accounted for transfers between categories at fair value with any unrealized holding gain or loss reported in earnings. Should transfers instead be accounted for at amortized cost or should unrealized holding gains or losses be deferred?

16. Should the effective date of the statement be the beginning of 1994 for entities with calendar-year fiscal years?

17. Should the statement permit disclosure of the pro forma effects of retroactive application? The ED would have prohibited disclosure of pro forma effects, because they could only be based on making retrospective assumptions about management's intent.

18. Is the distinction between measuring impairment of debt securities under the investments ED and measuring impairment of loans that are not securities under the loan impairment ED appropriate? The investments ED required that impairment be measured based on fair value. Accordingly, the Board planned to eliminate investments in debt securities from the scope of the ED, Accounting by Creditors for Impairment of a Loan, which required that impairment be measured by discounting expected cash flows at the security's effective interest rate.

19. Should the proposed statement provide detailed guidance on other-than-temporary impairment? The ED did not provide comprehensive guidance on other-than-temporary impairment, which involved issues beyond the scope of the project.

20. Are the disclosures required by the ED sufficient?
\end{abstract}




\section{Table 5}

Economic Consequences and Other Arguments Cited by Respondents

1) The resulting volatility would be misleading and confusing to the public.

m) The proposal would have a negative impact on earnings and capital.

n) The approach is piecemeal, because assets are marked to market, but liabilities are not.

o) The market for long-term capital would be impaired if investors avoided long-term investments.

p) Poor business decisions would result and long-term earnings would be impaired if portfolio terms were shortened.

q) The statement would be costly to administer.

r) Market values provide more relevant information.

s) Market valuations are not available on local bonds.

t) The rules are too subjective and provide the opportunity for abuse.

u) The proposal would have an adverse effect in terms of regulatory sanctions or the cost of FDIC insurance.

v) The statement would result in increased litigation against accountants. 


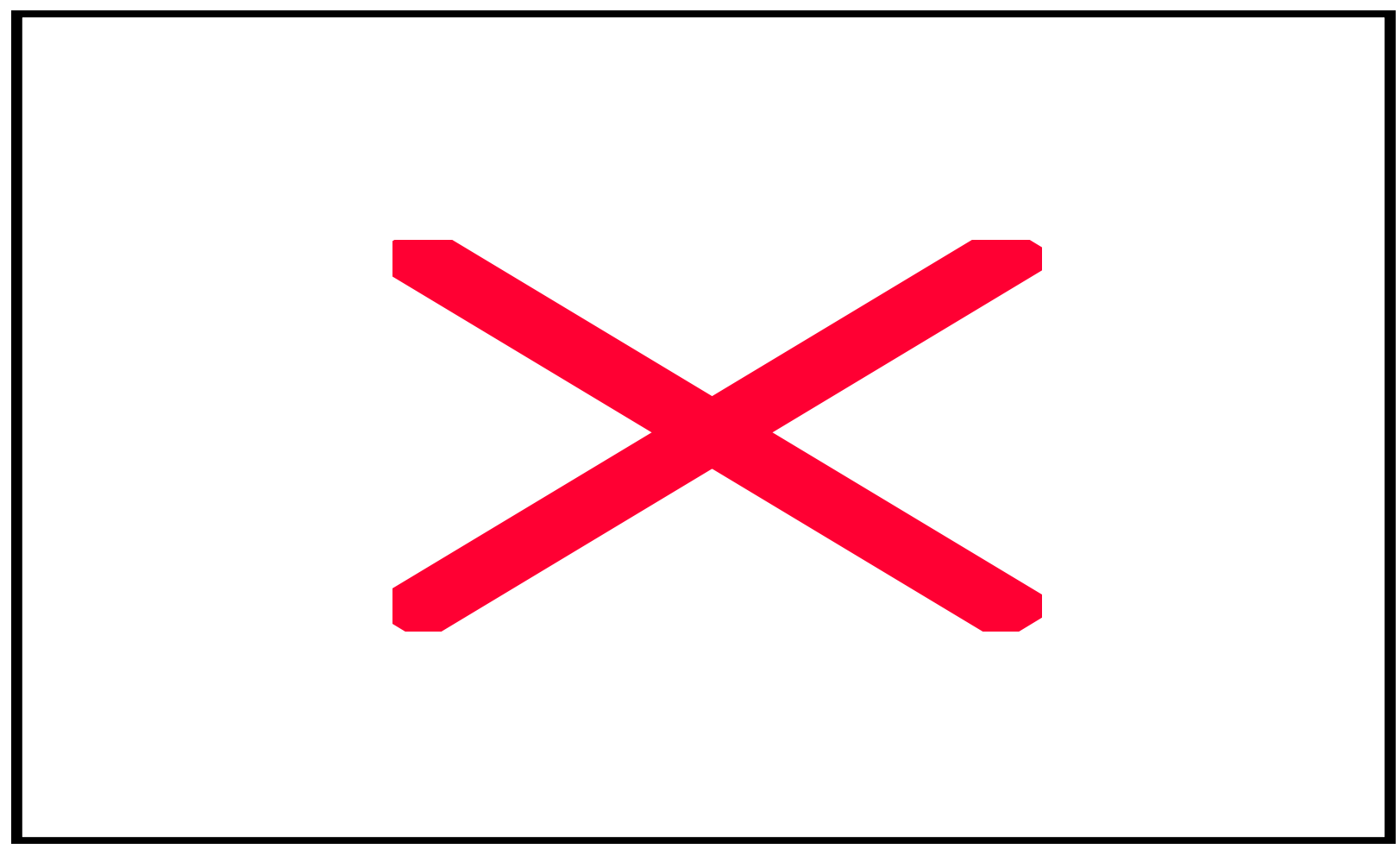


The Journal of Applied Business Research

Volume 19, Number 2

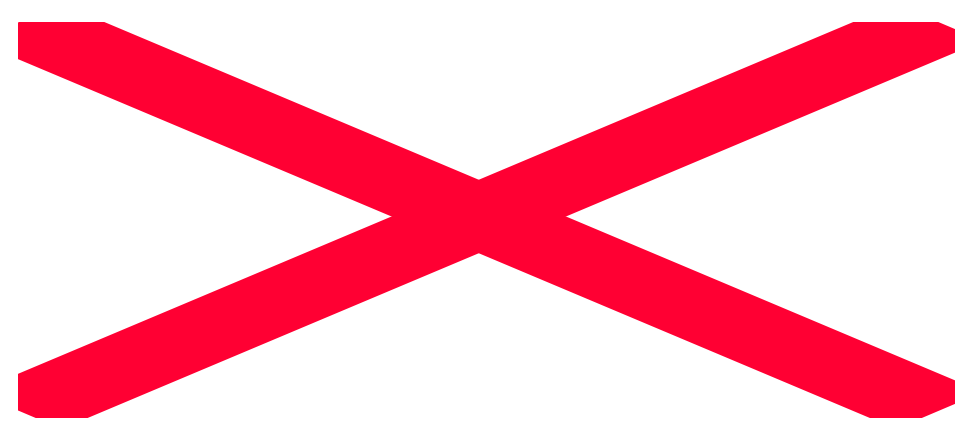




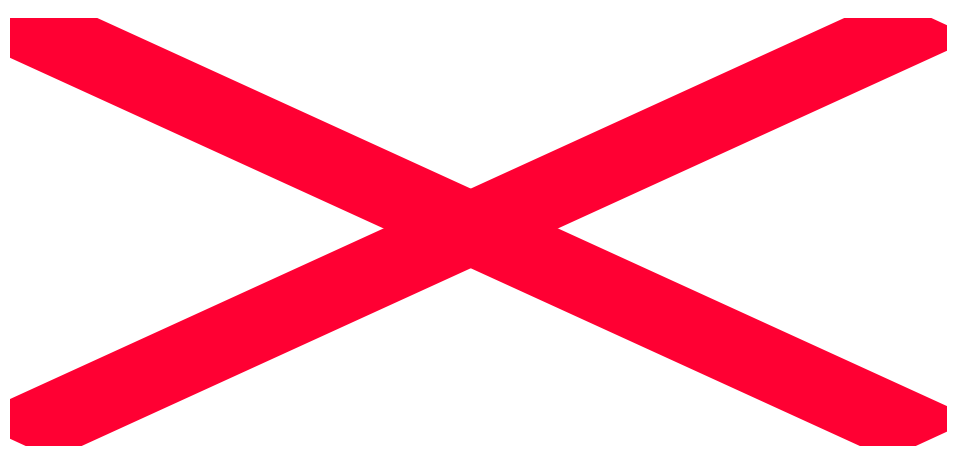




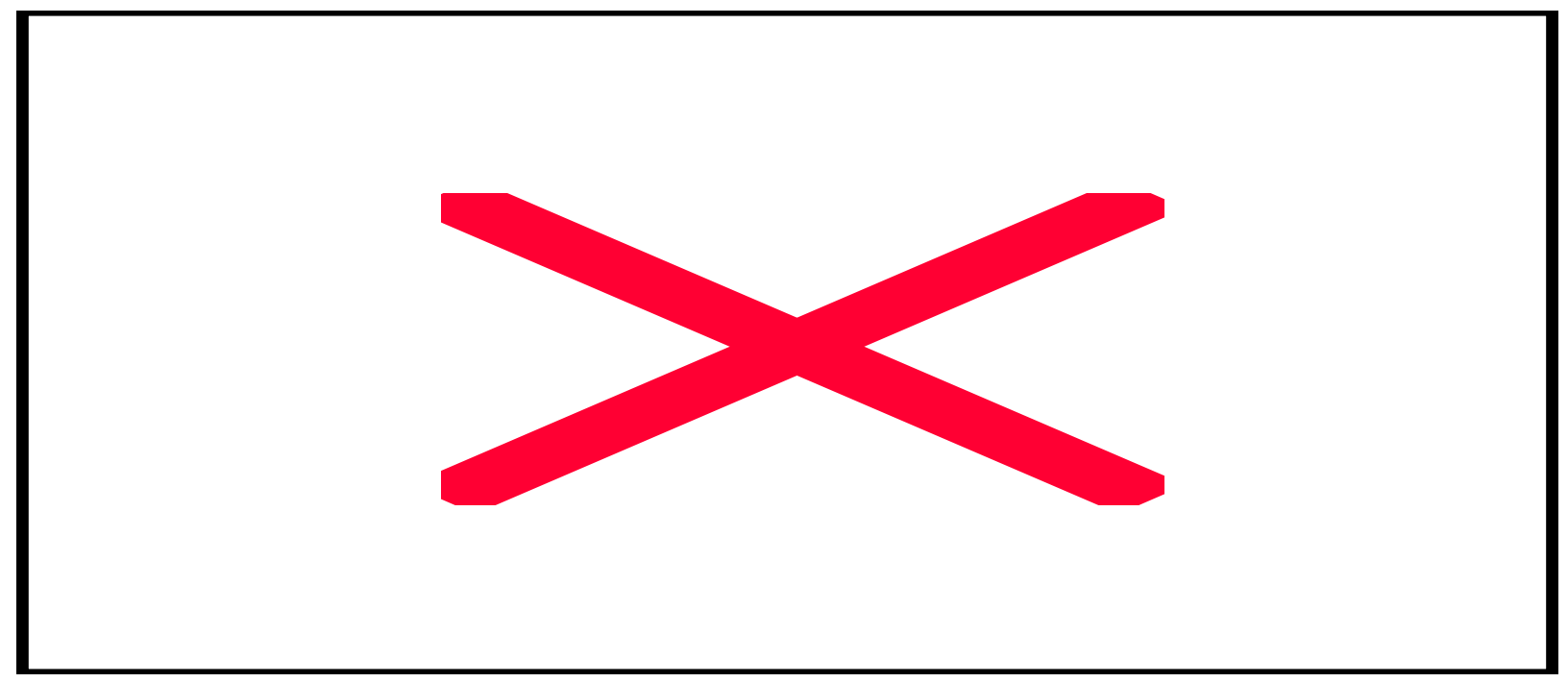

